See discussions, stats, and author profiles for this publication at: https://www.researchgate.net/publication/322988702

\title{
A Holistic Perspective on the International Market Selection Phenomenon
}

Article in Journal for East European Management Studies · January 2018

DOI: 10.5771/0949-6181-2018-4-579

CITATION

1

3 authors:

(2)

Susana Costa e Silva

Universidade Católica Portuguesa

152 PUBLICATIONS 218 CITATIONS

SEE PROFILE

Raquel $f$ Ch Meneses

University of Porto

52 PUBLICATIONS 97 CITATIONS

SEE PROFILE

Some of the authors of this publication are also working on these related projects:

Business Case Roadmap View project

Strategic Management View project

\section{Joanna Radomska \\ 12. Wroclaw University of Economics}

28 PUBLICATIONS 57 CITATIONS

SEE PROFILE 


\section{Journal of East European Management Studies}

Editorial Committee: Thomas Steger (Editor-in-chief), University of Regensburg | Rainhart Lang, Chemnitz University of Technology | Irma Rybnikova, Hochschule Hamm-Lippstadt

Advisory Board: Eckhard Dittrich, Otto-von-Guericke-University of Magdeburg | Miklós Dobák, Corvinus University Budapest | Ivan Nový, University of Economics Prague | Anna Soulsby, Nottingham University Business School | Dieter Wagner, University of Potsdam

Honorary Board: Ed Clark, Royal Holloway University of London | Vince Edwards, Buckinghamshire College | N. Holden, University of Leeds | Dirk Holtbrügge, University of Erlangen-Nürnberg | Fred Luthans, University of Nebraska Lincoln | Sheila M. Puffer, Northeastern University Boston | Rudi Schmidt, Friedrich-Schiller-University of Jena | Raoul Üksvärav †, University of Tallinn | Hartmut Wächter ${ }^{\dagger}$, University of Trier | Ingo Winkler, University of Southern Denmark

\section{Table of Contents}

\section{Articles}

Susana Costa e Silva, Raquel Meneses, Joanna Radomska 


\section{Editorial Board}

R. Alas †, Estonian Business School | G. Bakacsi, Budapest Business School | K. Balaton, University of Miskolc | Y.E. Blagov, St. Petersburg State University | S. Blazejewski, Alanus University | D.J. Bourne, Henley Business School | Z. Buzády, Corvinus University of Budapest | D. Catana, Technical University of Cluj-Napoca | T. Čater, University of Ljubljana | S.-O. Collin, Free University of Scania | B. Dallago, Università di Trento | $\mathbf{M}$. Dowling, University of Regensburg | T. Elenurm Estonian Business School | J. Erpenbeck, SIBE Herrenberg | J.H. Fisch, University of Economics Vienna | A. Geigenmüller, Ilmenau University of Technology | M. Geppert, Friedrich-Schiller-University of Jena V. Golikova, Higher School of Economics, Moscow | I. Gurkov, Higher School of Economics, Moscow B. Heidrich, Budapest Business School| J. Hentze, Technical University of Braunschweig | N. Hermes, University of Groningen | G. Hollinshead, University of Hertfordshire | S. Hüsig, Chemnitz University of Technology | A. Ishikawa, Chuo University | A. Jaklič, University of Ljubljana | J. Kovac, University of Maribor | K. Liuhto, Turku School of Economics | S. Llaci, University of Tirana | C. Makó, Hungarian Academy of Science Budapest | M. Malý, University of Economics Prague | W. Mayrhofer, Vienna University of Economics and Business | S. Michailova, Auckland University Business School J.-P. Neveu, Université de Pau \& Pays de l'Adour | R. Nurmi, Turku School of Economics | A. Panibratov, St. Petersburg State University | M. Pawlak, University of Warsaw | A. Pocztowski, Cracow University of Economics | E. Polyakov, Flowserve Al Rushaid Ltd., Saudi Arabia | T. Postma, University of Groningen | D. Pučko, University of Ljubljana | A. Remisova, Comenius University Bratislava | A. Schuh, Vienna University of Economics and Business | T. Specker, University of Applied Sciences Kiel | E. Szabo, Johannes-Kepler-University Linz | P. Wald, University of Applied Sciences Leipzig | A. Wasowska, University of Warsaw

Herausgeber/Editorial Committee: Prof. Dr. Thomas Steger, Universität Regensburg, Wirtschaftswissenschaftliche Fakultät, Lehrstuhl für BWL II, insb. Führung und Organisation, Universitätsstr. 31, 93053 Regensburg; Prof. Dr. Rainhart Lang, Technische Universität Chemnitz, Fakultät für Wirtschaftswissenschaften, BWL V Lehrstuhl für Organisation und Arbeitswissenschaft, Thüringer Weg 7, 09126 Chemnitz; Prof. Dr. Irma Rybnikova, Hochschule Hamm-Lippstadt, Marker Allee 76-78, D-59063 Hamm

Redaktion/Editorial Office: Prof. Dr. Thomas Steger, Universität Regensburg, Wirtschaftswissenschaftliche Fakultät, Lehrstuhl für BWL II, insb. Führung und Organisation, Universitätsstr. 31, D-93053 Regensburg, Tel.: +49 / 941 / 943-26 80, Fax: +49 / 941 / 943-42 06; E-Mail: Thomas.Steger@wiwi.uni-regensburg.de

Druck und Verlag/Printing and Publishing: NOMOS Verlagsgesellschaft mbH \& Co. KG, Postfach 100 310, D-76484 Baden-Baden, Tel.: 07221 / 21 04-0, Fax: 072 21 / 21 04-27, E-Mail: nomos@nomos.de

Bezugsbedingungen/Subscription rates 2018: Die Zeitschrift erscheint viermal im Jahr. Jahresabonnement für Privatpersonen 98,00 $€$ (Print und Online), für Studierende (unter Einsendung eines Studiennachweises) 40,00€ (Print und Online), für Institutionen 229,00 € (Print und Online; Mehrfachnutzung/unbegrenzte Anzahl an Online-Nutzern). Einzelheft 30,00 € (Print). Alle Preise inkl. MwSt., zzgl. Versandkostenanteil. Bestellungen beim örtlichen Buchhandel oder direkt bei der Nomos Verlagsgesellschaft, Baden-Baden. Kündigungsfrist: 3 Monate vor Kalenderjahresende.

Anzeigen/Advertising: Sales friendly Verlagsdienstleistungen, Pfaffenweg 15, D-53227 Bonn, Tel.: +49 / 228 / 97 89 80, Fax:+49 / 228 / 9789 820, E-Mail: roos@sales-friendly.de

Urheber- und Verlagsrechte/Copyrights and Publishing Rights: Die Zeitschrift sowie alle in ihr enthaltenen einzelnen Beiträge und Abbildungen sind urheberrechtlich geschützt. Jede Verwertung, die nicht ausdrücklich vom Urheberrechtsgesetz zugelassen ist, bedarf der vorherigen Zustimmung des Verlags. Mit der Annahme zur Veröffentlichung überträgt der Autor dem Verlag das ausschließliche Verlagsrecht für die Zeit bis zum Ablauf des Urheberrechts. Eingeschlossen sind insbesondere auch das Recht zur Herstellung elektronischer Versionen und zur Einspeicherung in Datenbanken sowie das Recht zu deren Vervielfältigung und Verbreitung online oder offline ohne zusätzliche Vergütung. Nach Ablauf eines Jahres kann der Autor anderen Verlagen eine einfache Abdruckgenehmigung erteilen; das Recht an der elektronischen Version verbleibt beim Verlag. Namentlich gekennzeichnete Beiträge geben nicht in jedem Fall die Meinung der Herausgeber/Redaktion oder des Verlages wieder. Unverlangt eingesendete Manuskripte - für die keine Haftung übernommen wird - gelten als Veröffentlichungsvorschlag zu den Bedingungen des Verlages. Die Redaktion behält sich eine längere Prüfungsfrist vor. Eine Haftung bei Beschädigung oder Verlust wird nicht übernommen. Bei unverlangt zugesandten Rezensionsstücken keine Garantie für Besprechung oder Rückgabe. Es werden nur unveröffentlichte Originalarbeiten angenommen. Die Verfasser erklären sich mit einer nicht sinnentstellenden redaktionellen Bearbeitung einverstanden.

Der Nomos Verlag beachtet die Regeln des Börsenvereins des Deutschen Buchhandels e.V. zur Verwendung von Buchrezensionen.

ISSN 0949-6181

\section{Nomos}




\title{
A Holistic Perspective on the International Market Selection Phenomenon*
}

\author{
Susana Costa e Silva, Raquel Meneses, Joanna Radomska**
}

This work seeks to identify the factors that lead to the selection of a specific country as an international location for foreign investment. Using three case studies of Portuguese firms that have internationalized to Poland, we were able to identify three different types of behaviour that led to the selection of the same international market location: systematic, relational and mimetic. Despite international market selection being a common topic of research in international business, few studies have focused on the rationale behind the selection of a specific target market. This study shows that market characteristics are decisive when firms intentionally seek a foreign market to enter, but are of less importance when country selection is motivated by rising business opportunities, a firm's existing relationships (following the client's strategy), or cost and risk reduction, in the form of mimetic behaviour.

Keywords: international market selection; isomorphism; internationalization; Poland. Jel codes: F21, F23

\section{Introduction}

To reduce the risk involved in acting abroad, it is normally accepted that companies should acquire knowledge (Johanson and Vahlne 1977). There are various options by which firms can do this (Andersen/Buvik 2002); for instance, firms can acquire knowledge via secondary data (systematic international market selection [IMS] [Root 1982]), via internationalization (experiential knowledge [Johanson/Vahlne 1977; Blomstermo et al. 2004]), or via their relationships (network-based knowledge [Sharma/Blomstermo 2003 Johanson/Vahlne 2009]). However, all these routes are complicated (Saen 2011) and time consuming (Ellis 2000; Harms/Schiele 2012). To overcome these obstacles, some firms prefer to use a different approach: they imitate others' behaviours. This raises the question of whether knowledge about the market is necessary in IMS. Hence, the main goal of this paper is to explore the factors that affect location choice and to check whether knowledge is one of the determinants. To obtain that goal,

* Received: 03.09.15, accepted: 16.09.17, 3 revisions.

** Susana Costa e Silva (Correspondent author), Universidade Católica Portugue _ Católica Porto Business School, Rua Diogo Botelho, 1327, 4169-005 Porto, Portugal = a@porto.ucp.pt. Main research interests: international marketing, strategic marketing, alliances and networks, international business.

Raquel Meneses, University of Porto, School of Economics and Management. Main research interests: international marketing, family business, business diplomacy and networks.

Joanna Radomska, Wrocław University of Economics, Strategic Management Department. Main research interests: strategic management, strategy execution, operational risk management.

JEEMS, 23 (4) 2018, 529 - 552

DOI: 10.5771/0949-6181-2018-4-529 
the perspective of Portuguese location decisions is described, and Poland is considered as the destination of Portuguese investment.

In 2013, Poland was among the eighth largest destinations of Portuguese direct investment, and one of the biggest investment markets in Eastern and Central Europe. According to the Portuguese Central Bank, the total amount invested in Poland more than doubled in the period 2009 to 2013, from EUR 63.8 million to EUR 153.3 million. This paper attempts to analyse why firms select the same international market when expanding abroad. It aims to understand this phenomenon when applied to IMS, focusing on Poland and a specific group of international investors: Portuguese firms. Our objective is to deeply analyse the literature that explains IMS, as most extant studies on this phenomenon have been based on the idea that knowledge is capital. Moreover, the empirical setting used - Poland - is of particular relevance for the fulfilment of our objectives, because it provides data that enables us to devise a theoretical framework on the IMS phenomenon.

These contributions are examined in the context of existing literature, a review of which can be found in the next section. A description of our methodology follows, in which we outline our use of three different case studies. In the discussion, we aim to respond to our research question by applying the proposed framework, drawing on the literature. Some consistencies and discrepancies are highlighted in the conclusion, in which the theoretical and practical contributions are also outlined, as well as the limitations and suggestions for further research.

\section{Approaches to international market selection}

There are different ways of overcoming the obstacles that normally accompany the IMS decision. Which method is chosen usually depends on the previous experience, the resources owned and the existing relations. This raises a question as to whether it is obligatory to posses knowledge about the market being entered (Moen, Gavlen, Endres 2004), or whether this factor is not so important. This way, three approaches to IMS - systematic, relational and mimetic - will be discussed in order to uncover the role knowledge plays in the IMS process.

\section{A systematic approach to IMS}

The selection of a target market involves uncertainty and complexity; the decision to implement a given strategy is typically based on a multidimensional strategic analysis, which usually leads to the key decision on implementing the strategy defined. This is an even more complicated task when the target market is a foreign one, as this adds more risk to the equation. Selection involves choosing one option in preference over others (Soules 2014). The literature on IMS refers to traditional and relational IMS, dividing the former into systematic and 
non-systematic (or opportunistic) (Root 1982). In both situations, knowledge is presented as a key factor in the selection. However, gaining knowledge is not always easy, and doing so can sometimes be very expensive and time consuming. According to Burpitt and Rondinelli (2000), obtaining knowledge is a major challenge in business, but little can be done without it in terms of IMS. When firms adopt a systematic approach they often follow a formalized decision process, using sophisticated techniques for data collection and statistical methods to analyse the diverse data collected in order to evaluate the attractiveness of potential markets. Some firms use external partners to collect data and obtain knowledge; others attempt to do this by themselves, analysing macro- and micro-environmental data from internal and external sources (Papadoupoulos/ Denis 1988; Musso/Francioni 2014).

A systematic framework is also proposed by Ayal and Zif (1979), who discuss the planning and evaluation of market expansion strategies. Theoretically speaking, a systematic approach is considered to comprise several stages (Root 1998; Johansson 1997; Koch 2001); however, empirical data indicate a gap between systematic models and the practice of management (Rahman 2001). In a study conducted by Musso and Francioni (2014), only 24.9\% of companies indicated the use of a systematic approach, which may have been the result of difficulties in accessing information and knowledge, as well as the challenge of limited resources. The process also seems to be too time consuming and expensive, especially for small and medium-sized enterprises (SMEs) (Ellis 2000; Harms/ Schiele 2012). Furthermore, the proposed frameworks may be impractical as they may not take into account the specificity of the sector in question ( $\mathrm{Pa}-$ padopoulos et al. 2002; Annushkina/Trinka Colonel 2013). In addition, the strategic and experimental dimensions of market selection are not considered (Grip$\mathrm{srud} /$ Benito 2005).

The alternative to the systematic process is the opportunistic approach. Several studies (e.g. Kobrin 1979; Cavusgil 1985) favour the use of a non-systematic approach to IMS; such authors claim that firms have limited capacity to acquire and process all the information required, and should therefore adopt a more opportunistic perspective in selecting markets (Bradley 1995). We can observe this non-systematic approach in the original Uppsala Model (Johanson/Vahlne 1977), in which firms are believed to internationalize in an incremental way, gradually overcoming psychic and geographical distance (Johanson/Wiedersheim-Paul 1975; Palmero et al. 2013). According to the model, selection is not based on specific assessment criteria; instead, internationalization starts in psychically and geographically close markets, only then moving to moderately close markets.

The opportunistic approach is also discussed in studies in which the authors emphasize the importance of factors such as intuition and experience (Brouthers/ 
Nakos 2005), and other apparently irrational decision variables (Ellis 2000; Musso/Francioni 2012). This is particularly noticeable in the case of SMEs, which have fewer resources to commit to a systematic approach (Nowiński/ Rialp 2013). A company's stability and resistance to change are also identified as relevant factors in this type of decision (Liberman-Yaconi et al. 2010). In this context, SMEs take a non-systematic approach (Stray et al. 2001). SMEs appear to be heavily influenced by the minimization of costs associated with access to information, as well as their own learning processes (Vissak et al. 2012).

\section{A relational approach to IMS}

Factors associated with relationships and networks of contacts are also regarded as elements that affect decisions concerning international expansion and the selection of a specific market. These factors are not to be ignored (Agndal/Axelsson 2002), as many decisions are made based on information disseminated by these contacts, regardless of their location. A study conducted by Moen et al. (2004) also demonstrates that SMEs use the mediation of other companies in this process, and that there is a correlation between experience in international business, the selection of the target market and the form of entry. Andersen and Buvik (2002) state that the choice of market(s) emerges from the level of business relations; in this context, "firms' ties provide channels for sharing knowledge as well as the motivation to do so" (Sharma/Blomstermo 2003: 744). In 1988, Johanson and Mattsson pointed out that there are four types of international firms, which are categorized by their degree of internationalization and the degree of internationalization of the network to which they belong. For instance, firms in an initial stage of internationalization, and that belong to a highly internationalized market, are considered to be late starters and as such are prone to learn through the experience of the other members of the network and establish their markets on this basis. The network approach suggests that the interdependence and interaction between actors in a network have an impact on all internationalization configurations (Håkansson/Waluszewski 2002). In addition, as mentioned by Silva et al. (2012: 144), "networks mean information and experience flows". Silva et al. claim that firms learn with their network, thus using second-hand knowledge. In this situation, firms develop observational or vicarious learning by observing others' actions and the consequences that follow from them (Michailova/Wilson 2008).

\section{A mimetic approach to IMS}

Another IMS option seems to be connected to imitation, wherein firms copy others' approaches. DiMaggio and Powell (1983) argue that a firm's imitation of the strategic actions of other companies is related to a desire to improve its position and to the pursuit of legitimacy, including social legitimacy. This is why 
companies may also be motivated to go abroad or intensify their internationalization processes via isomorphic pressures influenced by social norms and values (Kostova/Roth 2002). Therefore, it is worth examining the phenomenon of institutional isomorphism, which can be defined as the process of gradually resembling other firms within the same institutional environment (DiMaggio/ Powell 1983). The main advantage for the organization engaged in imitation comes from the external environment, as the firm gains legitimacy by showing alignment with other organizations (Scott 2001). As suggested by Salomon and $\mathrm{Wu}$ (2012), companies decide to display isomorphism in their strategy to reduce the distance between the home and host countries. The trend for mimesis may be evident in several circumstances, specifically concerning the decision of which markets to serve and the entry mode to be used ( $\mathrm{Lu} 2002)$.

When organizations considered to be trend-setters are subject to imitation (Haveman 1993), their behaviour is said to be mimetized. The results of several studies indicate that this behaviour also applies to decisions on the location of foreign investments (Henisz/Delios 2001; Guillén 2002; Purgal-Popiela 2015). This concerns not only selection of the target market, but also the fact that imitators believe it is the means by which to establish foreign operations (Guler/ Guillén 2006), or achieve internal (within the multinational enterprise) and external (in the host context) institutional embeddedness (Narula 2014). This behaviour can be observed in the selection of location for foreign operations. As mentioned by Kim (2015), attention should be paid to entry-stage location choices, as well as to the firm's behaviour and its inherent performance, which attracts attention and stimulates imitative action.

As stated by Bikhchandani et al. (1998), when decisions need to be made firms can develop their own analyses and make their own choices, sometimes as part of a learning process. Alternatively, they can take a shortcut, accepting the options that others have made. When it becomes necessary to make an IMS decision, firms can make their own choices (based on their own knowledge or analysis), or save time and money by imitating others.

On the basis of the literature reviewed, our understanding is that a framework combining the three abovementioned approaches can be offered in order to better understand the role played by knowledge in explaining location choice.

\section{Conceptual framework proposed for IMS}

Based on the above, we can state that firms may select the same international market because they use a systematic approach based on the same data, because they use a relational approach and they follow a partner, or because they use a mimetic approach and imitate others. From this perspective, if IMS does not follow a systematic approach, it can be considered opportunistic. 
The approaches described above are plotted in a framework in which we attempt to summarize the various alternative ways of understanding the IMS phenomenon according to different lenses (see Figure 1). In the following sections, the dimensions of the framework are explained in more detail.

\section{Figure 1: Different approaches explaining location choice}

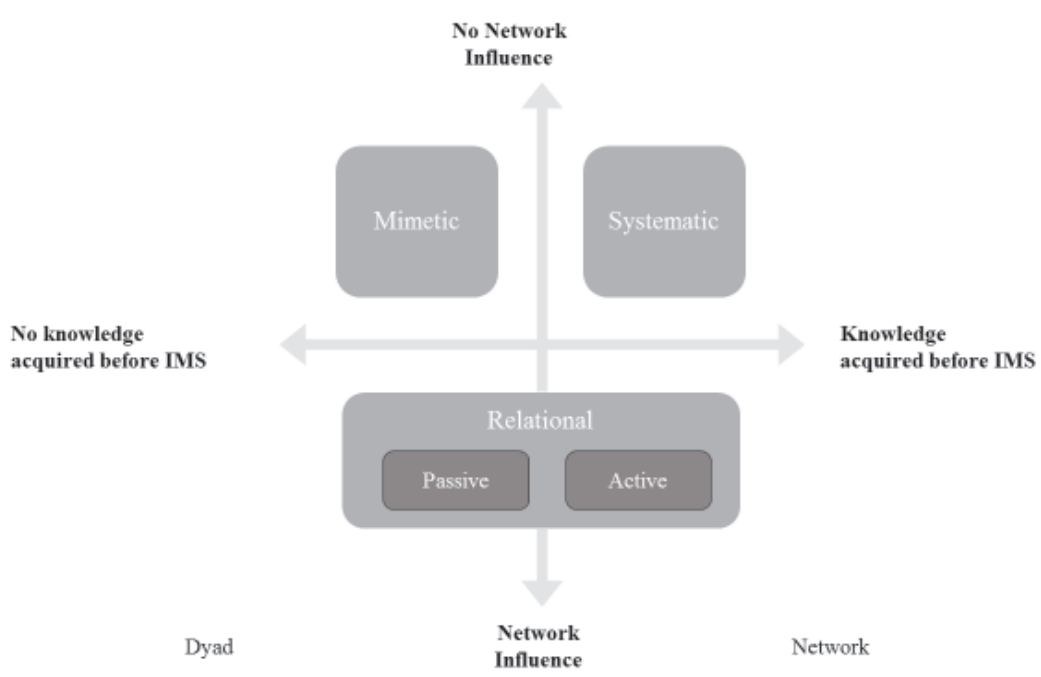

The importance of the systematic approach in the proposed framework

Organizations "facing similar decision problems and information sets take similar decisions" (Bikhchandani/Sharma 2000: 281). If firms adopt a systematic approach to entering international markets, they do so by being formally aware of opportunities to collect and analyse information. If different firms use the same mental process, criteria selection and analysis, they will end up making more or less the same decisions because their frameworks lead them to a similar output, and not because they have imitated others. This was the case with some companies willing to invest in Eastern European markets, which adopted an open market economy model after the $1990 \mathrm{~s}$, thus drawing the attention of several international investors. After this transition to an open economy, some obstacles that may have hindered firms from entering certain markets lessened, making new entry easier and influencing firms to select these markets. Thus, the decision to invest in a new market can be considered the culmination of a set of reflexive processes, in which firms - on the basis of similar information - take similar actions because this follows a rational and systematic line of thought. 


\section{The importance of the relational approach in the proposed framework}

Hadley and Wilson (2003) operationalized the network approach adopted by Johanson and Mattsson (1988) for the internationalization process, stating that international experiences and contact with other organizations can be an invaluable asset, such that the positioning of the firm in the network is essential to IMS. For instance, many suppliers are first introduced to particular markets through their buyers. As stated by Martin et al. (1994: 567), "The vertical link between suppliers and buyers provides information to suppliers when a current or potential buyer expands into a foreign location." Accordingly, Fabian and Molina (2009) argue that it is very important to maintain customers, regardless of whether the company is internationalizing or remaining domestic, particularly for SMEs. When firms internationalize, they need to rely on and maintain their domestic providers - those with whom they are used to doing business and whom they know well - to the greatest extent possible. As looking for providers in a new market can be expensive and risky, firms prefer to maintain relationships with providers from their domestic markets. In these cases, we have what Grönroos (1999) calls a client-following strategy, which encapsulates a passive relational way of entering markets. This happens when client-following firms operate in a network by helping and pressuring other firms to go abroad (Majkgard/Sharma 1998). Even though the literature predominantly refers to situations in which the initiative is taken by the client firm, the initiative can sometimes depart from the company wishing to go abroad but with no other means of obtaining the knowledge of where to go than from the partners that are members of its networks. In this case, they actively rely on their relations to form their decisions. This is what we can term an active relational means of entering markets: firms actively seek information that will allow them to decide where to go.

Both passive and active approaches to using relations capture a strategy that is less expensive (Erramilli/Rao 1990) and less risky (Majkgard/Sharma 1998).

In terms of the relational view - passive or active - a firm that was previously a follower or an information gatherer may turn into a followed or an influential partner. Thus, it may also contribute later to the introduction of others to the new market.

\section{The importance of the mimetic approach in the proposed framework}

In 1955, Hoffer claimed that "When people are free to do as they please, they usually imitate each other". Because firms are managed by people, the firms themselves may imitate one another, given the chance to do so. As noted by Lieberman and Asaba (2006: 366), "Firms may imitate to avoid falling behind their rivals or because they believe that others' actions convey information." 
According to Chan et al. (2006), several studies provide evidence that the market entry decision is influenced by the previous foreign expansion of business groups, encapsulating imitative behaviour. Haunschild and Miner (1997) claim that two types of imitative behaviour influence the location decision: frequencybased imitation and trait-based imitation. "Frequency-based imitation is a pure social imitative process in which a firm imitates the structures, practices and decisions that have been adopted by growing numbers of other firms" (Delios et al. 2008: 175). Firms tend to imitate the actions taken by a large number of quasisimilar organizations, thus leading to a bandwagon effect (Abrahamson/ Rosenkopf 1993). This reflects a vicious cycle, in which an increasing number of companies taking a certain action leads to an increase in the number of companies willing to take the same action.

Trait-based imitation is a more selective process, in which firms imitate actions taken and decisions made by high-status or highly similar firms (Henisz/Delios 2001). The idea of following successful firms is very appealing because firms believe "that a decision used by a successful firm is likely to have a positive outcome if imitated" (Lu 2002: 23). According to neo-institutional theory, which conceptualizes the environment as an organizational field (Kostova et al. 2008), in the context of uncertainty, prior decisions made by other organizations inform and provide legitimacy for future decisions (DiMaggio/Powell 1983; Henisz/ Delios 2001). This applies to a large extent to small-sized entities, for which entry into foreign markets is associated with overcoming internal barriers and the need to acquire organizational legitimacy, which is considered to be one of the most important external constraints on internationalization (Kostova/Zaheer 1999). In the same vein, Kostova et al. (2008) claim that organizational survival depends on the firm's ability to align with the institutional environment. Organizational actors increase the firm's chances of coping better with a changing and uncertain environment when they comply with the institutional pressures of the new environment by employing actions already legitimized by others.

As shown by Haunschild and Miner (1997), organizations tend to implement practices that have benefited other entities. Regardless of whether this takes place unintentionally or deliberately, it involves the mobilization of valuable information that provides the basis for strategic decisions. According to Lieberman and Asaba (2006), some organizations adopt the same behaviour without any thought; this resembles information cascade theory (Bikhchandani et al. 1998), which "occurs when it is optimal for an individual, having observed the actions of those ahead of him, to follow the behavior of the preceding individual without regard to his own information" (Bikhchandani et al. 1992: 994). This is not necessarily a learning process, as learning is the ability to acquire new knowledge that the venture can use in its operations (Zahra/Hayton 2008). Here, it is possible that knowledge is not acquired and the behaviour is not about ob- 
servational learning, as described by Casillas et al. (2009), or vicarious learning, as described by Bruneel et al. (2010).

Much of the time, the behaviour is only about observing actions and simply imitating them. However, as Bonaccorsi (1992) notes, this does not constitute knowledge transfer; rather, it increases experiential knowledge as a consequence of the imitated action. Thus, firms imitate the instigator, generating a wave that will also be imitated in the future. In the context of this bandwagon effect, firms often do not realize that identical actions can yield different outputs due to their individual differences. Regarding IMS, once large companies choose a given market as a target, a wave is formed and other firms will select the same international market. It is important to note that "experience (or experiment) is more costly and time consuming than imitation", so imitation appears to be "an attractive decision rule" (Lieberman/Asaba 2006: 373). As Li and Ding (2013: 510) note, "Mimetic pressure is caused by the need to cope with uncertainty through imitating organizations perceived to be more legitimate or more successful."

In line with the literature presented above, we believe that firms select their international markets using one of the three possibilities described, depending on the knowledge acquired and on the network influence.

\section{Methodology}

To describe and explore the business phenomenon of IMS within a real-life context, a descriptive, non-positivist approach is used. Exploratory research tends to follow this approach as the objective is to select a sample with a particular purpose in mind, rather than to produce statistical generalizations of findings (Remenyi et al. 1998). The appropriateness of this research method for the present work is supported by Yin $(1984,2003)$. As the research aims to investigate the factors affecting location choice, the study of particular companies is appropriate. The empirical basis for this investigation is provided by case studies of Portuguese firms that have entered the Polish market. A purposive sample of three case studies was chosen, with cases selected due to their relevance to the study. According to Yin (2003), a case study is an empirical enquiry used to investigate a contemporary phenomenon within its real-life context when the boundaries between it and the context are not clearly evident and multiple sources of evidence can be used. We followed this approach by selecting cases that fulfilled the following conditions: (1) the firm should be registered in Portugal and owned by Portuguese-based interests; (2) the firm should have operations in Poland and not just direct or indirect exports to that country; (3) the firms should belong to different business sectors, have different origins within the country and be of different sizes, thus providing a glimpse of the Portuguese reality. The case study firms' characteristics are summarized in Table 1. 


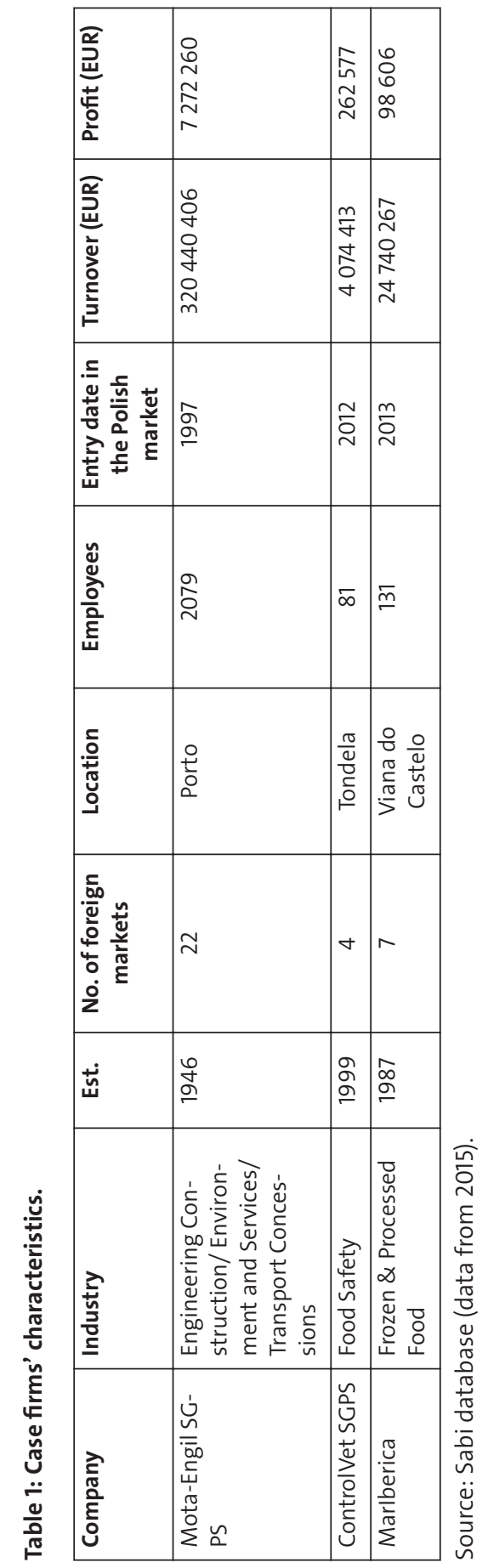


Unstructured interviews were conducted with the executives of each firm responsible for internationalization decisions. These interviews allow interviewers to "be free to explore interesting or unexpected findings as they arise" (Adams et al. 2005:83), which is important in exploratory studies such as this one. In all cases, the interviewee was one of the founders and currently a chairman of the firm. The chief financial officer (CFO) of Marlbérica was also interviewed. All interviews were on average one hour in duration. The interviews were recorded and later transcribed for content analysis. The two initial categories considered were knowledge acquisition and the existence of networking influence. The interview transcription ensured the consistency of analysis. During the process, other issues emerged, including intention to go to Poland, the introduction of the possibility to go to Poland, and the existence of an imitation process in place. Reliability was ensured concerning the constructs extracted. To enrich the chosen methodology, additional sources, such as newspaper articles and firms' websites, were also used.

\section{Findings}

According to the Polish Information and Foreign Investment Agency, there are around 150 companies with Portuguese capital currently operating in Poland, 30 of which are recognized as important investors. At the end of 2016, Portuguese foreign direct investment (FDI) in Poland totalled EUR 1.2 billion. In 2014, the equity capital (net) was EUR 41.5 million, with reinvested earnings (net) of EUR 66.4 million and total FDI inflows (net) of EUR 18.5 million. The total direct investment income (net) was EUR 118.4 million (up from EUR 92.9 million in 2013). Although there was a drop of 32.6\% (comparing 2013 and 2014), Poland was still one of the most important foreign markets as of 2014. Most Portuguese enterprises are located in the Mazowieckie, Wielkopolskie and Łódzkie voivodeships, and belong to the following sectors: finance, retail, construction, automotive, plastics processing, renewable energies, food and beverages (Duda 2016). Portugal is expecting to continue investing in the banking and energy sectors in the coming few years.

\section{Mota-Engil SGPS}

Background. Since the $1980 \mathrm{~s}$, the company has grown substantially due to the great increase in infrastructure development in Portugal, which was triggered by funding from the European Union (EU). The entry and pre-entry funds obtained from the EU played an important role for companies at that time and allowed significant investments in the construction of infrastructure. However, it was expected that European funds would be drastically reduced for countries entering the EU in 1986, including Portugal, and would be redirected to Eastern European countries, such as Poland, the Czech Republic and Hungary. This is why Mota-Engil began looking at these markets in 1995. In the words of the chair- 
man, António Mota, "At that time it was already clear for the firm that these funds would be further allocated to another place. And Poland was our choice."

IMS approach. In 1997, Mota-Engil began its activity in Poland with two contracts for the construction and rehabilitation of 142 bridge structures on one of the Polish motorways. The company executives were aware that the infrastructure in Eastern European countries at that time was relatively poor and the rural population was quite high (30-40\%). Thus, a significant urbanization movement was anticipated, as was, consequently, a great demand for construction work. Mota-Engil established an initial set of countries - Poland, the Czech Republic and Hungary - as target markets, and began looking for entry possibilities in each. The first, most important selection criterion mentioned was the market potential. In addition, Poland was assumed to be a central point of a new business area, i.e. Central Europe. Indeed, in 2010, after a set of acquisitions and mergers, Mota-Engil established its main division for Central Europe in Poland: MotaEngil Central Europe S.A.:

When we think about internationalization, the first thing that comes to our mind is the market potential. And Poland and other Eastern European countries had a huge potential. We are talking about 40 million people, and if we consider the countries around, which we could manage from a single Polish market position, we can talk about 300 million people.

The chairman of Mota-Engil was enthusiastic about the market potential back then, and still is today: "We hope that one day Mota-Engil Poland will have enough dimension to reach the Russian market as well, and might also be able to participate in the Ukrainian one. Yes, we think that this is a location with great potential." As confirmed by the chairman, the selection of Poland as an internationalization destination "was a strategic decision at that time. We were not following anything; it was a concretization of our strategy. If we were following something it was the market that we knew would grow."

The strategy for the internationalization of Mota-Engil in Poland and other foreign markets has proven successful, as confirmed by a press release on the firm's website:

Foreseeing that the development of Europe will pass through Central Europe, the founder of the Group, Manuel António da Mota, made the decision to analyse the possibility of moving forward the international Group, thus far present only in Portugal and Africa. After studying the possibilities of the market entry, Mota-Engil started its activity in Poland in 1997, extending later to the Czech Republic and Hungary. ${ }^{l}$

The press release also states:

Currently, and after 15 years, Mota-Engil is considered one of the leading companies in Poland, operating through the whole Polish territory and from this country to other Central and Eastern

1 Retrieved from www.mota-engil.pt on 15 March 2015. 
European markets. This gives rise to the implementation of a strategy that passes through the concentration of regional resources in Poland. ${ }^{2}$

\section{Controlvet SGPS}

Background. ControlVet operates in the food safety industry, providing food and water quality control assistance to primary production and consultancy services. It also provides services to firms in other sectors, such as food production, food distribution, and hotels and restaurants. In Portugal, one of the largest clients of the firm is the Jerónimo Martins Group (JMG), which is also the owner of discount stores in Poland, Biedronka.

In recent years, JMG has faced some issues regarding food quality in its supermarkets in Poland. The procedures regarding food quality control in Poland are slightly different from those in Portugal: the supplier carries out the entire quality control process, so the seller is not responsible for quality control concerning food distribution. Therefore, the relationship between quality control firms and suppliers is much closer than that between distributors and quality control firms. This may lead to a situation in which the food quality control firm, on behalf of the supplier, is responsible for approving the quality of products.

IMS approach. Under the circumstances described, JMG approached ControlVet with the proposal of ControlVet providing food control services for the JMG business in Poland. "We started our operation in Poland because JMG asked us to do so. It was not exactly our plan to start new operations abroad this year." At that particular moment in time, the company was not considering entering Poland, except in a hypothetical sense:

I was thinking about Poland, of course. I watch the news and I read newspapers. But Poland is a country of 40 million people, and the market is quite saturated and very competitive nowadays. When we started our operations in Cape Verde, we were the unique food quality control firm there. Poland is large. Poland is different.

After receiving the proposition from JMG, no further evaluation of the market was conducted. ControlVet initiated operations to enter the Polish market.

ControlVet's founder's statements can be confirmed by Portuguese newspaper articles: "ControlVet, which operates in the food security sector, is acquiring $50 \%$ of one company in Poland." The aim, according to João Cotta, the president of the company, was "to take advantage of the fact that Jerónimo Martins is our client in Portugal and can be also in the Polish market. (...) In fact, it is a ride on the back of an important group, which is already very well established in the Polish market."

2 Retrieved from www.mota-engil.pt on 15 March 2015. 


\section{Marlbérica}

Background. Marlbérica is a Portuguese SME that specializes in processing and marketing deep-frozen fish and seafood and pre-cooked products, such as fish sticks and hake fillets. The company started its activities by marketing fresh fish. Marlbérica has been a provider for JMG for approximately 12 years. JMG is a demanding client as there are many restrictive procedures and quality requirements in Portugal. JMG is also one of the largest players in the supermarket field in Portugal, which has boosted the company to grow internationally. As mentioned by Martinho Silva, CFO of Marlbérica, "we are also evolving somehow, because they [JMG] have a set of rules that they require the supplier to fulfil."

As pointed out by José Fernandes, another executive of MarIbérica, the collaboration between Marlbérica and JMG over the years has made the firm aware of Poland as a potential new market: "Because of our regular supplies from the Jerónimo Martins Group, we believed that we could also have some opportunities for one or more specific products to be launched in that country [Poland]."

IMS approach. The company observed the success of JMG and understood that it was possible, even for a smaller firm, to enter Poland successfully. Initially, it tried to sell its products to Biedronka (the JMG Polish supermarket chain). This process was time-consuming and complex, as the company was dealing with the Polish subsidiary. This business was unsuccessful, but, following the examples of JMG and other Portuguese firms, MarIbérica established a partnership with an independent Polish company, which facilitated its entry into the Polish market.

\section{Discussion}

Based on these three case studies, we were able to verify that each firm decided to initiate its activities in a given country mainly on the basis of three lines of reasoning: (1) the firm intended to go international and therefore looked for a new foreign market to enter (in this case, the characteristics of the market were primarily considered in a framework that assisted the firm in evaluating alternatives); (2) the firm was presented with a specific opportunity to enter, which may have arisen from its being part of a specific network or having a close relationship with a client (typically, this happens when a client requests that the firm follows it into a new foreign market); (3) the firm used others' decisions to legitimize its selection (in this case intentionally imitating others).

The first case, Mota-Engil, used a systematic approach. This firm decided to expand abroad and therefore studied market conditions. According to its strategic analysis, Poland seemed to be an attractive destination due to its low level of development and large population. First, as some legal and institutional barriers had disappeared, the company saw a market opportunity. In that particular case, the sector of activity was also important as it was predicted to grow. Second, the 
size of the company lowered the risk of failure, considering such factors as the availability of resources and its financial situation.

The second case comprises what may be called a relational approach. It was not ControlVet's initiative to go to Poland, but JMG was (and remains) an important client. Following this client ensured that the firm could obtain more orders. This was not the result of IMS, but of a commitment to follow the client to an international market. As an SME, the company is able to develop deeper relationships with clients compared to a large corporation. Thus, some decisions, such as the decision of which international markets to serve, are strictly linked to the client's strategy.

The third case constitutes a mimetic approach to IMS. MarIbérica watched the success of JMG and other Portuguese firms and decided to enter the Polish market (without analysing the market beforehand). Marlbérica assumed that JMG had good information and this informational cascade legitimized its decision. As an SME, it could not spend as much money or time on analysing the market situation as a large enterprise might. Following other enterprises seemed to be a reasonable way of minimizing the risk.

The cases analysed each show a kind of isomorphism in which agents exhibit the same type of behaviour (even though their motivations may differ). There seems to be evidence of these firms following others on the basis of a relational approach, or a mimetic one, in which they followed larger firms into a market. However, Mota-Engil, a larger firm, seems not to have followed any other firm. This represents a systematic approach to IMS as the firm had no herd to follow; as shown in the case study, Mota-Engil sought and pursued active market opportunities abroad. This, of course, is imperative for a business that depends on project tenders that take up the firm's capacity for some years but not permanently.

The other two cases describe two different attitudes. In the case of ControlVet, we see a traditional client-following approach, typical of services, as claimed by Fitzsimmons and Fitzsimmons (2010). ControlVet seems to have chosen Poland due to a request from a client, following a company that also happened to be in that market. As for Marlbérica, we understand that it followed a true mimetic approach because it intentionally looked for opportunities in Poland due to what it regarded to be the experience of other larger firms there, in particular JMG.

This research establishes some important ties to existing literature. First, the case studies confirm the generally assumed division of IMS approaches into systematic and non-systematic (or opportunistic) modes (Papadopolous/Denis 1988; Brewer 2001; Andersen/Buvik 2002). Furthermore, the study shows that the systematic approach is more likely to be used by firms intentionally seeking new foreign markets to enter. The decision drivers in this case are expected to be 
mostly market-related. According to Dunning (2000), firms seek to establish activities where they can enjoy the best advantages, a position corroborated by the Mota-Engil chairman. This Portuguese company chose Poland due to the expected inflow of EU funds. Hence, Poland presented itself as the most profitable market in which to invest at that time. As stated by Brouthers et al. (2009), the systematic approach allows us to regard IMS as a process that balances firm and country-market characteristics. Firms following this approach - generally larger companies - believe their decision is not based on other firms' actions, but on their understanding that they are pursuing opportunities in that specific market. This is more common in larger firms with more resources to commit to internationalization decisions.

SMEs tend to use the non-systematic approach (Cavusgil 1985). The countries selected are not the result of a strategy that pushes for the most profitable allocation of resources, but of a response to changing conditions in the firm environment. This opportunistic perspective is reflected in the cases of ControlVet and Marlbérica. However, while in the case of ControlVet the opportunity arose due to an invitation on the client's side, for Marlbérica the opportunity arose when a wave of firms going into Poland became evident. In this situation, a bandwagon effect can be identified.

In accordance with Cavusgil and Godiwalla (1982), the IMS applied by SMEs such as ControlVet is closely linked to relationships and networks, as well as personal and professional experience. For ControlVet, the firm's existing network was central to the decision to internationalize to Poland. The market itself was not directly chosen by the firm (even though a significant number of Portuguese firms decided to serve it); it was determined by its customer, JMG. In the case of such a client-following phenomenon, the characteristics of the foreign market are not especially important because the firm is focused on how to follow the client into that market, rather than appraising the market's attractiveness.

The cost of gathering relevant data is likely to be the main barrier for SMEs in using the systematic approach. In this situation, firms can use a mimetic approach based on an informational cascade. MarIbérica is a small firm, and understood that it could select an international market in a low-cost way. The firm recognized the legitimacy of JMG's decisions and followed this group. This is in line with the idea of informational cascades: firms base their decisions on the actions of larger firms as they believe that if larger firms are successful, it is because they have a good basis on which to ground their decisions.

These cases highlight that various motivations can lead to the same decision; at the same time, it is important to note that imitation can be a rational way of selecting international markets. It is less time-consuming and risky compared to 
other approaches, even though one firm's means of success may not prove successful for another firm.

As the wave begins, the imitators of imitators (laggards) could be very distant from the original information source, such that it may be difficult to determine whether the information remains useful. Another problem that may arise is that as time goes by, the market evolves and information that was useful before may no longer be up to date.

These cases also illustrate the key role of networks in the internationalization process, as was pointed out in 1988 by Johanson and Mattsson. The network itself can be a source of international opportunities, or it can serve as an instigator for firms. In both contexts, it could give rise to an opportunity to regard relationships as an asset.

The cases analysed in this article present different ways of looking at the same phenomenon. Although there are different theoretical views describing the issue of IMS, the holistic perspective seems to enable more coherent analysis of the chosen approach and the key drivers affecting the final decision (see Table 2), which contributes to expanding existing explanations of IMS. From this holistic perspective, we claim that knowledge might not be the crucial factor, considering that if firms "mimetize" others' choices, they may be saving time and money on IMS.

Table 2: The holistic perspective on the IMS phenomenon.

\begin{tabular}{|c|c|c|c|c|}
\hline Theoretical view & $\begin{array}{l}\text { IMS ap- } \\
\text { proach }\end{array}$ & & Key drivers & $\begin{array}{l}\text { Knowl- } \\
\text { edge ac- } \\
\text { quisition }\end{array}$ \\
\hline $\begin{array}{c}\text { International } \\
\text { Business }\end{array}$ & Systematic & \multicolumn{2}{|c|}{ Market-seeking characteristics } & Mandatory \\
\hline \multirow{2}{*}{ Networking } & $\begin{array}{c}\text { Relational } \\
\text { Active }\end{array}$ & \multirow{2}{*}{$\begin{array}{l}\text { Partners re- } \\
\text { garded as as- } \\
\text { sets }\end{array}$} & $\begin{array}{c}\text { Searching for stakehold- } \\
\text { ers }\end{array}$ & Mandatory \\
\hline & $\begin{array}{l}\text { Relational } \\
\text { Passive }\end{array}$ & & Following stakeholders & $\begin{array}{l}\text { Not ac- } \\
\text { quired }\end{array}$ \\
\hline Mimetic & Mimetic & \multicolumn{2}{|c|}{ Bandwagon effect } & $\begin{array}{l}\text { Not ac- } \\
\text { quired }\end{array}$ \\
\hline
\end{tabular}

\section{Conclusions}

This research has aimed to understand the role played by knowledge in the process of IMS. In order to respond this question, we used evidence from Portuguese companies investing in Poland, in order to identify factors that drove this trend. To address the research problem, three case studies have been presented and several approaches have been identified. The large firm is understood to have adopted a systematic approach to IMS, while the other two cases repre- 
sent SMEs displaying a non-systematic approach, but of different types: while one used a relational approach (following a client), the other used a form of mimetic behaviour (imitating another firm). In both cases, the specific foreign market characteristics of Poland were not directly assessed or considered by the firms. In the follow-the-client situation, the firm was ensuring involvement with a customer; in the imitation situation, the decision was based on another firm's view that entering Poland would lead to success and therefore be a good decision. This allowed us to conclude that even though knowledge is of capital importance, and mandatory in most of the cases, in the "passive relational" and "mimetic" situations proposed in our framework (see Figure 1), knowledge may be absent when the process of selecting international markets is initiated.

\section{Theoretical contribution}

One of the most relevant contributions of this paper is that it identifies and considers three distinct approaches to IMS. This study supports the separation of IMS approaches into two categories: systematic and non-systematic (Papadopolous/Denis 1988; Brewer 2001; Andersen/Buvik 2002). However, there are situations in which it is important to understand what other firms are using as decision criteria. This study also confirmed that the systematic approach is more likely to be adopted by large companies, while the non-systematic approach tends to be chosen by SMEs. This is due to the fact that SMEs cannot afford the considerable effort that the systematic approach requires. The study also shows that the market characteristics are decisive when firms intentionally seek a foreign market to enter, but are of much less importance in the case of country selection as a response to a business opportunity. In the ControlVet case, the market was not directly selected by the company through the evaluation of alternatives; rather, it was imposed by the opportunity to obtain orders from an existing client already working in Poland. This is an example of a passive relational approach, in which no knowledge was acquired during the selection process.

Imitation occurs when firms recognize an information cascade and use this to select a market. Gaining knowledge is a time-consuming and costly process, but imitating the actions of others is a way of overcoming these constraints. This option may be legitimized by the success of the imitated firm (trait-based imitation), or by the large number of firms choosing the same option (frequencybased imitation).

The increasing relevance of a firm's network is clearly shown in this study. In addition to the benefits of a firm's relationships identified by Johanson and Mattsson (1988), our study finds that a firm's existing relationships may lead to international expansion without knowledge acquisition. Our findings allow us to conclude that, under some circumstances, it is possible to "invent" the knowledge necessary for decision making. 


\section{Practical contribution}

This paper provides a better understanding of the factors driving Portuguese companies to choose Poland as a foreign market for their operations. The study identifies three different factors that lead Portuguese companies to enter the Polish market: (1) market-specific characteristics, (2) using partners (namely clients) as assets and (3) imitating others, thereby creating a bandwagon effect.

The findings of the study provide interesting insights for other Portuguese companies wishing to expand their operations into international markets, presenting non-systematic approaches (relational and mimetic) as rational options. Firms must understand which firms they can imitate and which idiosyncrasies may be due to the instigator's/initiator's first-mover advantage, industrial sector, network of contacts, management team, etc. They should also keep in mind that this approach, if conducted well, may result in significant cost savings (resources and time). Furthermore, approaches can be complementary: the opportunity may be the result of this behaviour, but specific information may also be sought - for instance, through secondary data sources, or a combination of previous experiences, which can represent a relevant alternative to a rational management decision. Lack of previous knowledge can be overcome by imitating or following others.

\section{Limitations and suggestions for future investigation}

The major limitation of this study is the small number of case studies, which should be increased in future studies to guarantee reliability (a rather difficult process considering the sensitive information needed). Nonetheless, the study was able to cover all three main IMS approaches identified, which was only possible because we used a theoretical sampling procedure. It would be interesting to continue the interviews with Portuguese companies that have operations in Poland to gain a deeper understanding of the outcomes. It would also be useful to observe, from a financial point of view, the performance results of instigators, followers and imitators. Divestment decisions could shed light on other factors not mentioned in this study; for instance, it would be interesting to ascertain whether, in this situation, other firms would have seen divestments as a signal to avoid following the wave. This is another limitation that future studies may seek to overcome.

\section{References}

Abrahamson, E./Rosenkopf, L. (1993): Institutional and competitive bandwagons: Using mathematical modelling as a tool to explore innovation diffusion, in: Academy of Management Review, 18, 3, 487-517.

Adams, R./Fujii, A./Mackey, A. (2005): Research methodology: Qualitative research, in: Sanz, C. (ed). Mind and context in adult second language acquisition, Washignton, DC: Georgetown University Press, 69-101. 
Agndal, H./Axelsson, B. (2002): Internationalisation of the firm - The influence of relationship sediments, in: Havila, V./Forsgren, M./Håkansson, H. (eds), Critical perspectives on internationalisation. Amsterdam/New York, NY: Pergamon.

Andersen, O./Buvik, A. (2002): Firms' internationalization and alternative approaches to the international customer/market selection, in: International Business Review, 11, 347-363.

Annushkina, O. E./Trinca Colonel, R. (2013): Foreign market selection by Russian MNEs -beyond a binary approach? in: Critical Perspectives on International Business, 9, 1/2, 58 87.

Ayal. I./Zif, J. (1979): Market expansion strategies in multinational marketing, in Journal of Marketing, 43, 84-94.

Bikhchandani, S./Sharma, S. (2000): Herd behavior in financial markets, in: IMF staff papers, 279-310.

Bikhchandani, S./Hirshleifer, D./Welch, I. (1992): A theory of fads, fashion, custom, and cultural change as informational cascades, in Journal of Political Economy, 992-1026.

Bikhchandani, S./Hirshleifer, D./Welch, I. (1998): Learning from the behavior of others: Conformity, fads, and informational cascades, in: The Journal of Economic Perspectives, 151170.

Blomstermo, A./Eriksson, K./Lindstrand, A./Sharma, D. D. (2004): The perceived usefulness of network experiential knowledge in the internationalizing firm, in: Journal of International Management, 10(3), 355-373.

Bonaccorsi, A. (1992): On the relationship between firm size and export intensity, in: Journal of International Business Studies, 23, 4, 605-635.

Bradley, F. (1995): Perspectives on international services marketing and management, in: Advances in Services Marketing and Management, 4, 313-335.

Bradley, F. (1999): International marketing strategy. Hertfordshire: Prentice Hall.

Brewer, P. (2001): International market selection: Developing a model from Australian case studies, in: International Business Review, 10, 155-174.

Brouthers, L./Nakos, G. (2005): The role of systematic international market selection on small firms' export performance, in: Journal of Small Business Management, 43, 4, 363-381.

Brouthers, L. E./Mukhopadhyay, S./Wilkinson, T.J./Brouthers, K.D. (2009): International market selection and subsidiary performance: A neural network approach, in: Journal of World Business, 44, 3, 262-273.

Bruneel, J./Yli-Renko, H./Clarysse, B. (2010): Learning from experience and learning from others: How congenital and interorganizational learning substitute for experiential learning in young firm internationalization, in: Strategic Entrepreneurship Journal, 4, 2, 164-182.

Burpitt, W. J./Rondinelli, D. A. (2000): Small firms' motivations for exporting: To earn and learn? in: Journal of Small Business Management, 38, 4, 1.

Casillas, J. C./Moreno, A. M./Acedo, F. J./Gallego, M. A./Ramos, E. (2009): An integrative model of the role of knowledge in the internationalization process, in: Journal of World Business, 44, 3, 311-322.

Cavusgil, S. T. (1985): Guidelines for export market research, in: Business Horizons, November-December, 27-33.

Cavusgil, S. T./Godiwalla, Y. M. (1982): Decision-making for international marketing: A comparative review, in: Management Decision, 20, 4, 47-54. 
Chan, C. M./Makino, S., /Isobe, T. (2006): Interdependent behavior in foreign direct investment: The multi-level effects of prior entry and prior exit on foreign market entry, in: Journal of International Business Studies, 37, 5, 642-665.

Delios, A./Gaur, A. S.,/Makino, S. (2008): The timing of international expansion: information, rivalry and imitation among Japanese firms, 1980-2002, in; Journal of Management Studies, 45, 1, 169-195.

DiMaggio, P./Powell, W. (1983): The Iron Cage revisited: Institutional isomorphism and collective rationality in organizational fields, in: American Sociological Review, 48, 2, $147-$ 160.

Duda, D. (2016): Foreign investment climate in Poland. Warsaw: Polish Information and Foreign Investment Agency.

Dunning, J. H. (2000): The eclectic paradigm as an envelope for economic and business theories of MNE activity, in: International Business Review, 9, 2, 163-190.

Ellis, P. (2000): Social ties and foreign market entry, in: Journal of International Business Studies, 31, 3, 443-469.

Erramilli, M./Rao, C. (1990): Choice of foreign market entry mode by service firms: Role of market knowledge, in: Management International Review, 30, 2, 135-150.

Fabian, A. P. F./Molina, H. (2009): Understanding decisions to internationalize by small and medium-sized firms located in an emerging market, in: Management International Review, $49,5,537-563$.

Fitzsimmons, J./Fitzsimmons, M. (2010): Administração de serviços: operações, estratégia e tecnologia da informação. 6. ed. Porto Alegre: Bookman.

Gripsrud, G./Benito, G. (2005): Internationalization in retailing: Modelling the pattern of foreign market entry, in: Journal of Business Research, 58, 12, 1672-1680.

Grönroos, C. (1999): Internationalization strategies for services, in: Journal of Services Marketing, 13, 4/5, 290-297.

Guillén, M. (2002): Structural inertia, imitation, and foreign expansion: South Korean firms and business groups in China, 1987-1995, in: Academy of Management Journal, 45, 509525.

Guler, I./Guillén, M. (2006): Social networks, uncertainty, and market choice. Working Paper.

Hadley, R. D./Wilson, H. I. (2003): The network model of internationalisation and experiential knowledge, in: International Business Review, 12(6), 697-717.

Håkansson, H./Waluszewski, A. (2002): Managing technological development. IKEA, the environment and technology. London: Routledge.

Harms, R./Schiele, H. (2012): Antecedents and consequences of effectuation and causation in the international new venture creation process, in: Journal of International Entrepreneurship, 10, 2, 95-116.

Haunschild, P./Miner, A. (1997): Modes of interorganizational imitation: The effects of outcome salience and uncertainty, in: Administrative Science Quarterly, 42, 472-500.

Haveman, H. (1993): Follow the leader: Mimetic isomorphism and entry into new markets, in: Administrative Science Quarterly, 38, 593-627.

Henisz, W./Delios, A. (2001): Uncertainty, imitation, and plant location: Japanese multinational corporations, 1990-1996, in: Administrative Science Quarterly, 46, 443-475.

Hoffer, E (1955): The passionate state of mind, aphorism 33. New York: Harper. 
Johansson, J. (1997): Global marketing, foreign entry, local marketing and global management. Chicago, IL: McGraw-Hill.

Johanson, J./Mattsson, L.-G. (1988): Internationalization in industrial systems - a network approach, in: Hood, N./Vahlne, J.-E. (eds), Strategies in global competition. New York: Croom Helm, 287-314.

Johanson, J./Vahlne, J. E. (1977): The internationalization process of the firm - a model of knowledge development and increasing foreign market commitments, in: Journal of International Business Studies, 23-32.

Johanson, J./Vahlne, J. E. (2009): The Uppsala internationalization process model revisited: From liability of foreignness to liability of outsidership, in: Journal of International Business Studies, 40, 9, 1411-1431.

Johanson, J./Wiedersheim-Paul, F. (1975): The internationalization of the firm - four Swedish cases, in: Journal of Management Studies, 12, 3, 305-322.

Kim, H. (2015): Should birds of a feather flock together? Agglomeration by nationality as a constraint in international expansion, in: AIB Insights, 15, 3, 11-12.

Kobrin, S. J. (1979): Political risk: A review and reconsideration, in: Journal of International Business Studies, 10, 1, 67-80.

Koch, A. (2001): Factors influencing market and entry mode selection: Developing the MEMS model, in: Marketing Intelligence \& Planning, 19, 5, 351-361.

Kostova, T./Roth, K. (2002): Adoption of an organizational practice by subsidiaries of multinational corporations: Institutional and relational effects, in: Academy of Management Journal, 45, 1, 215-233.

Kostova, T./Zaheer, S. (1999): Organizational legitimacy under conditions of complexity: The case of the multinational enterprise, in: The Academy of Management Review, 24, 1, 64 81.

Kostova, T./Roth, K./Dacin, T. (2008): Institutional theory in the study of multinational corporations: A critique and new directions, in: The Academy of Management Review, 33, 4, 994-1006.

Li, F./Ding, Z. (2013): The effect of institutional isomorphic pressure on the internationalization of firms in an emerging economy: Evidence from China, in: Asia Pacific Business Review, 19, 4, 506-525.

Liberman-Yaconi, L./Hooper, T./Hutchings, K. (2010): Toward a model of understanding strategic decision-making in micro-firms: Exploring the Australian information technology sector, in: Journal of Small Business Management, 48, 1, 70-95.

Lieberman, M. B./Asaba, S. (2006): Why do firms imitate each other? in: Academy of Management Review, 31, 2, 366-385.

Lu, J. (2002): Intra- and inter-organizational behavior: Institutional influences on Japanese firms' entry mode choice, in: Journal of International Business Studies, 33, 1, 19-37.

Majkgard, A./Sharma, D. D. (1998): Client-following and market-seeking strategies in the internationalization of service firms, in: Journal of Business-to-Business Marketing, 4, 3, 141.

Martin, X./Mitchell, W./Swaminathan, A. (1994): Recreating and extending buyer-supplier links following international expansion. Advances in Strategic Management, 10, 47-72. 
Michailova, S./Wilson, H. I. (2008): Small firm internationalization through experiential learning: The moderating role of socialization tactics, in: Journal of World Business, 43, 2 , 243-254.

Moen, Ø./Gavlen, M./Endresen, I. (2004): Internationalization of small, computer software firms: Entry forms and market selection, in: European Journal of Marketing, 38, 9/10, $1236-1251$.

Musso, F./Francioni, B. (2012): How do smaller firms select foreign markets? in: International Journal of Marketing Studies, 4, 6, 44-53.

Musso, F./Francioni, B. (2014): International strategy for SMEs: Criteria for foreign markets and entry modes selection, in: Journal of Small Business and Enterprise Development, 21, 2, 301-312.

Narula, R. (2014): Exploring the paradox of competence-creating subsidiaries: Balancing bandwidth and dispersion in MNEs, in: Long Range Planning, 47, 4-15.

Nowiński, W./Rialp, A. (2013): Drivers and strategies of international new ventures from a Central European transition economy, in: Journal for East European Management Studies, $18,2,191-231$.

Palmero, A./Herrera, J./Sabaté, J. (2013): The role of psychic distance stimuli on the EastWest FDI location structure in the EU. Evidence from Spanish MNEs, in: Journal for East European Management Studies, 18, 1, 36-65.

Papadopoulos, N./Denis, J. E. (1988): Inventory, taxonomy and assessment of methods for international market selection, in: International Marketing Review, 5, 3, 38-51.

Papadopoulos, N./Chen, H./ Thomas, D. R. (2002): Toward a tradeoff model for international market selection, in: International Business Review, 11, 2, 165-192.

Purgal-Popiela J. (2015): Managing international assignments in Polish companies operating in foreign markets - analysis of preliminary empirical results, in: Journal for East European Management Studies, 20, 1, 17.

Rahman, S. (2001): The international market selection process: A study of successful Australian international firms, in: Journal of International Marketing and Exporting, 6, 2, 150160.

Remenyi, D./Williams, B./Money, A./Swartz, E. (1998): Doing research in business and management. London: Sage.

Root, F. (1998): Entry strategies for international markets, revised and expanded. San Francisco, CA: John Wiley \& Sons.

Root, R. (1982): Foreign market entry strategy. New York: Amacom.

Saen, R. F. (2011): International market selection using advanced data envelopment analysis, in: IMA Journal of Management Mathematics, 22, 371-386.

Salomon, R./Wu, Z. (2012): Institutional distance and local isomorphism strategy, in: Journal of International Business Studies, 43, 343-367.

Scott, R. (2001): Institutions and organizations, 2nd ed. Thousand Oaks, CA: Sage.

Sharma, D. D./Blomstermo, A. (2003): The internationalization process of born globals: A network view, in: International Business Review, 12, 6, 739-753.

Silva, S./Pacheco, E./Meneses, R./Brito, C. (2012): The importance of second-hand knowledge in the revised Uppsala Model: Can European textiles producers export to China? in: Journal of Global Marketing, 25, 3, 141-160. 
Soules, A. (2014): Collections, selection, access, in: New Library World, 115, 5/6, 263.

Stray, S./Bridgewater, S./Murray, G. (2001): The internationalisation process of small, technology-based firms: Market selection, mode choice and degree of internationalisation, in: Journal of Global Marketing, 15, 1, 7-29.

Vissak, T./Francioni, B./Musso, F. (2012): MVM's nonlinear internationalization: A case study, in: Journal of East-West Business, 18, 4, 275-300.

Yin, R. K. (1984): Case Study Design and Methods. Beverly Hills: Sage Publishing.

Yin, R. K. (2003): Case study research design and methods, 3rd ed. Thousand Oaks, CA: Sage Publications.

Zahra, S. A./Hayton, J. C. (2008): The effect of international venturing on firm performance: The moderating influence of absorptive capacity, in: Journal of Business Venturing, 23, 2, $195-220$.

\section{Electronic resources}

ControlVet (2012): History. Available at www.controlvet.pt, accessed 15 March 2015.

Fellismino, E. (2011): ControlVet adquire uma empresa na Polónia. In http://economico.sapo. pt/noticias/controlvet-adquire-empresa-na-polonia_120788.html, accessed 17 June 2011.

Mota-Engil (2012): Press Room. Available at www.mota-engil.pt, accessed 15 March 2015. 